\title{
26. PALEOMAGNETISM OF BASALTS FROM ODP HOLE 648B ON THE MID-ATLANTIC RIDGE ${ }^{1}$
}

\author{
M. Mansour Bina, ${ }^{2}$ Yozo Hamano, ${ }^{3}$ Kristian Krammer, ${ }^{4}$ and Anita Wooldridge ${ }^{5}$
}

\begin{abstract}
Paleomagnetic parameters of 55 basalt samples from Hole $648 \mathrm{~B}$ on the Mid-Atlantic Ridge were studied. Negative NRM inclinations were found for 10 samples between 10 and $25 \mathrm{~m}$ sub-bottom depth. Several hypotheses related to this phenomenon are discussed. NRM intensities, susceptibilities, median destructive fields, and Koenigsberger ratios are slightly different for pillow and massive basalts. One can suggest from measured parameters that magnetic carriers for massive and pillow basalts are PSD titanomagnetite grains more or less close to PSD-MD threshold size with a low degree of alteration.
\end{abstract}

\section{INTRODUCTION}

An important aspect of drilling the Hole 648B was a direct penetration of the young, fresh so-called "zero age basalts" within a narrow accretion zone. These rocks therefore offer the possibility of investigations on the low temperature alteration as well as recent excursions of geomagnetic field. The primary objectives of paleomagnetic measurements were to determine (1) the intensity, inclination, and stability of the natural remanent magnetization (NRM); (2) the stable inclination of NRM; and (3) the identity and grain sizes of the magnetic carriers.

Over the drilled thickness of $50.5 \mathrm{~m}$, three lithological units could be identified; the top $30 \mathrm{~m}$ consists of aphyric or phyric pillow basalts with plagioclase and olivine; the next $3 \mathrm{~m}$ consists of vesicular, sparsely olivine-plagioclase phyric basalts; and the lowest unit consists of massive holocrystalline basalts.

\section{EXPERIMENTAL PROCEDURES}

Unfortunately, in spite of special technology made for bare rock drilling, the recovery rate was low and the number of oriented samples was limited. This resulted in large inaccuracy in the attribution of the samples with depth. During Leg 106 and 109, 22 samples were measured on board; 36 more samples were studied on shore ( 3 are duplicates of the same samples). In addition to the shipboard apparatus (see Detrick, Honnorez, Bryan, Juteau, et al., 1988), we have used a modified SSM-1 Schonstedt and a JR4, spinner magnetometers, Bartington MS2 and Kappa-Bridge susceptibility meters. Alternating field (AF) demagnetizations were done using a Schonstedt or a laboratory-made demagnetizer; the latter reaching 2800 Oe peak field (Le Goff, 1985).

\section{RESULTS}

Paleomagnetic results are listed in Table 1 by order of core numbers. Intensity $\left(J_{n}\right)$ of natural remanent magnetization (NRM) varies from 34 to $198\left(10^{-4} \mathrm{emu} / \mathrm{cm}^{3}\right)$ and does not seem to be dependent on the lithological type (Fig. 1A). Median demagnetizing field $\left(\mathrm{MDF}_{\mathrm{n}}\right)$ which is sensitive to the particle size of the magnetic grains and reflects in some way

\footnotetext{
I Detrick, R., Honnorez, J., Bryan, W. B., Juteau, T., et al., 1990. Proc. ODP, Init. Repts., 106/109: College Station, TX (Ocean Drilling Program).

${ }^{2}$ Laboratoire de Géomagnétisme du Parc Saint Maur; Université Paris 6 et Centre National de la recherche Scientifique.

${ }^{3}$ Earthquake Research Institute, University of Tokyo.

${ }^{4}$ Institut für Allgemeine und Angewandte Geophysik; Universität München.

${ }^{5}$ University of Miami, Marine Geology and Geophysics.
}

the coercivity, is slightly higher for pillows than for massive samples (Fig. 1C). Zijderveld diagrams show the absence of secondary components other than a very soft viscous magnetization (Fig. 2B). Magnetic susceptibilities $(\chi)$ are scattered with a tendency to increase with depth (Fig. 1D). Magnetic mineral content can also be a source of variation of NRM and susceptibility; so normalization by $\mathrm{J}_{\mathrm{s}}$ (induced saturation magnetization) may can give more information about domain structures. The highest values of $\chi$ belong to the last two cores from massive flow with presumably larger grain sizes. Koenigsberger ratio $(\mathrm{Q})$, calculated for $\mathrm{h}=0.4 \mathrm{Oe}$ (from IGRF data) averages 25 with standard deviation 13, and decreases significantly in the bottom unit (Fig. 1E). In general, we observe some tendency of magnetic parameters to change with lithological type however without an obvious trend.

Surprisingly, stable inclinations of NRM are negative for most of samples $\left(\mathrm{N}=10\right.$, averaging $-39^{\circ}$ with s.d. $\left.=14^{\circ}\right)$ between about 10 and $20 \mathrm{~m}$ depth (Fig. 1B). To a depth of 55 $\mathrm{m}$, the mean value of $49^{\circ}$ from 41 samples with positive stable inclination is very near to that of today's magnetic field (about $45^{\circ}$; exception for Sample 648B-15R-1, 58-60 cm; probably because of misorientation of this core piece having a small size). Four hypotheses could be made for this phenomenon:

1. It shows an excursion of earth magnetic field at the time of formation of these rocks. Its identification needs accurate dating of the samples in order to compare with other known data.

2. A self-reversed magnetization might be acquired by adjacent phases of titanomagnetites having different Curie temperatures (this can be seen from thermomagnetic analysis of these samples). However, no distinct multiphases are observed in these samples from thermomagnetic analyses (see rock magnetism in this volume). We have also produced a thermoremanent magnetization (TRM) in three of these samples in a laboratory field $(\mathrm{h}=0.4 \mathrm{Oe})$ in vacuum. Before and after heating, the susceptibility and for one sample hysteresis parameters, were measured in order to detect any mineralogical evolutions (Table 2). We have not observed any selfreversal of TRM in these experiments.

3. The collapse or falling of some of these rocks after their formation, due essentially to volcanic or tectonic activities in that region.

4. Rotation after drilling in the core barrel of core pieces having small sizes. This can give a misorientation to the core pieces.

The two last hypotheses are difficult to rule out, but we have to note that in the latter case, the rotation would have to be almost the same for neighboring samples, which seems unlikely. 
Table 1. Paleomagnetic data: depth in meters; $J_{n}=$ intensity of NRM in $10^{-4} \mathrm{emu} / \mathrm{cm}^{3} ; I_{s}=$ table inclinations in degrees; $\mathrm{MDF}_{\mathrm{n}}, \mathrm{MDF}_{\mathrm{a}}=$ median demagnetizing field for NRM and ARM in Oe; $\chi=$ magnetic susceptibility in $10^{-4} \mathrm{emu} / \mathrm{cm}^{3} \mathrm{Oe} ; \mathrm{Q}=$ Koenigsberger ratio; $\mathrm{J}_{\mathrm{a}}=$ intensity of $A R M$ in $10^{-4}$ $\mathrm{emu} / \mathrm{cm}^{3} ; \mathrm{MDF}_{\mathrm{a}}=$ median demagnetizing field for ARM in Oe.

\begin{tabular}{|c|c|c|c|c|c|c|c|c|c|c|}
\hline Sample & Depth & $\mathrm{J}_{\mathrm{n}}$ & $\mathrm{I}_{\mathrm{s}}$ & $\mathrm{MDF}_{\mathrm{n}}$ & $x$ & Q & $\mathbf{J}_{\mathbf{a}}$ & $\mathrm{MDF}_{\mathrm{a}}$ & $\mathrm{J}_{\mathrm{a}} / \mathrm{J}_{\mathrm{n}}$ & $\mathrm{MDF}_{\mathrm{a}} / \mathrm{MDF}_{\mathrm{n}}$ \\
\hline $1 \mathrm{R}-1,2-4$ & 1.93 & 119 & - & 57 & 4.72 & 63 & - & - & - & - \\
\hline $1 \mathrm{R}-1,17-20$ & 7.35 & 190 & 50 & 99 & 10.34 & 46 & - & - & - & - \\
\hline $1 \mathrm{R}-1,30-33$ & 7.82 & 142 & 72 & 64 & 15.07 & 24 & - & - & - & - \\
\hline $1 \mathrm{R}-1,59-62$ & 7.96 & 76 & 31 & 82 & 11.00 & 17 & - & - & - & - \\
\hline IR-1, 90-92 & 8.68 & 65 & 40.5 & 113 & 8.20 & 21 & 55 & 67 & 0.8 & 0.6 \\
\hline $1 \mathrm{R}-1,100-102$ & 8.90 & 48 & 43 & 120 & 5.66 & 21 & - & - & - & - \\
\hline $1 \mathrm{R}-1,130-132$ & 9.59 & 96 & 17 & 90 & 6.64 & 36 & - & - & - & - \\
\hline $1 R-1,143-145$ & 9.90 & 133 & 33 & 50 & 9.30 & 36 & 75 & 60 & 0.6 & 1.2 \\
\hline IR-1, 147-149 & 9.98 & 61 & 29 & 130 & - & - & - & - & - & - \\
\hline IR-2, 37-40 & 10.90 & 50 & -25 & 75 & 9.83 & 13 & - & - & - & - \\
\hline $1 \mathrm{R}-2,114-117$ & 12.67 & 131 & -13 & 110 & 4.21 & 78 & - & - & - & - \\
\hline IR-2, 117-119 & 12.74 & 91 & 15 & 109 & 6.16 & 37 & - & - & - & - \\
\hline $1 \mathrm{R}-2,124-126$ & 12.90 & 83 & -33 & 120 & 8.27 & 25 & - & - & - & - \\
\hline $1 R-3,14-16$ & 13.82 & 129 & -30 & 100 & 7.70 & 42 & - & - & - & - \\
\hline $1 \mathrm{R}-3,44-46$ & 14.51 & 77 & 16 & 140 & - & - & - & - & - & - \\
\hline $1 \mathrm{R}-3,68-70$ & 15.06 & 100 & -59 & 110 & 5.58 & 45 & - & - & - & - \\
\hline $3 \mathrm{R}-1,3-6$ & 14.52 & 68 & 0 & 45 & 4.81 & 35 & - & - & - & - \\
\hline $3 \mathrm{R}-1,29-31$ & 16.49 & 118 & -48 & 113 & 10.50 & 30 & 74 & 68 & 0.6 & 0.6 \\
\hline $3 \mathrm{R}-1,31-33$ & 16.64 & 132 & -45 & 89 & 13.12 & 25 & - & - & - & - \\
\hline $3 \mathrm{R}-1,57-59$ & 18.76 & - & - & - & 6.64 & - & - & - & - & - \\
\hline $3 \mathrm{R}-1,74-77$ & 19.89 & 53 & -40 & 45 & 6.27 & 21 & - & - & - & - \\
\hline $4 \mathrm{R}-1,35-37$ & 23.50 & 88 & 19 & 95 & - & - & - & - & - & - \\
\hline $5 R-1,4-6$ & 15.48 & 88 & -57 & 70 & 12.00 & 18 & 44 & 56 & 0.5 & 0.8 \\
\hline $5 \mathrm{R}-1,29-31$ & 21.30 & 34 & 64 & 290 & - & - & - & - & - & - \\
\hline $5 \mathrm{R}-1,32-35$ & 22.00 & 69 & 65 & 144 & 5.59 & 31 & - & - & - & - \\
\hline $6 \mathrm{R}-1,57-60$ & 28.91 & 162 & 38 & 56 & 17.80 & 23 & - & - & - & - \\
\hline $6 \mathrm{R}-1,69-71$ & 29.58 & 147 & 63 & 60 & - & $\overline{0}$ & - & - & - & - \\
\hline $6 \mathrm{R}-1,78-81$ & 30.08 & 166 & 82 & 41 & 18.00 & 23 & - & - & - & - \\
\hline $6 \mathrm{R}-1,132-135$ & 33.08 & 198 & 43 & 47 & 23.94 & 21 & - & - & - & - \\
\hline $8 \mathrm{R}-1,48-50$ & 25.92 & 127 & 44 & 70 & 14.00 & 23 & 63 & 64 & 0.5 & 0.9 \\
\hline $8 \mathrm{R}-1,52-54$ & 26.08 & 108 & 51 & 80 & 11.15 & 24 & - & - & - & - \\
\hline $8 R-1.65-67$ & 26.40 & 94 & 34 & 85 & 15.60 & 15 & 55 & 54 & 0.6 & 0.6 \\
\hline $9 \mathrm{R}-1,68-70$ & 26.72 & 119 & 38 & 59 & 14.14 & 21 & 40 & - & 0.3 & - \\
\hline $9 \mathrm{R}-1,71-73$ & 31.47 & 79 & 62 & 56 & 13.20 & 15 & 48 & 85 & 0.6 & 1.5 \\
\hline $9 \mathrm{R}-1,80-82$ & 32.00 & 77 & 75 & 86 & 13.32 & 14 & 33 & - & 0.4 & - \\
\hline $9 \mathrm{R}-1,84-86$ & 32.11 & - & - & - & 11.32 & - & - & - & - & - \\
\hline $13 \mathrm{R}-1,11-13$ & 25.56 & 120 & -36 & 69 & 14.00 & 21 & 45 & - & 0.4 & - \\
\hline $15 \mathrm{R}-1,4-6$ & 24.29 & 133 & 82 & 71 & 12.10 & 27 & 61 & 64 & 0.5 & 0.9 \\
\hline $15 \mathrm{R}-1,12-14$ & 24.86 & 103 & 54 & 106 & 8.70 & 29 & 79 & 109 & 0.8 & 1.0 \\
\hline $15 \mathrm{R}-1,58-60$ & 28.18 & 109 & -23 & 99 & 9.00 & 30 & 75 & 85 & 0.7 & 0.9 \\
\hline $15 \mathrm{R}-1,68-70$ & 28.90 & 72 & 33 & 100 & 8.02 & 22 & - & - & - & - \\
\hline $15 \mathrm{R}-1,85-87$ & 30.12 & 94 & 75 & 99 & 11.50 & 20 & 72 & 79 & 0.8 & 0.8 \\
\hline $15 \mathrm{R}-1,92-94$ & 30.62 & 54 & 84 & - & 12.30 & 11 & 56 & 79 & 1.0 & - \\
\hline $15 \mathrm{R}-1,111-113$ & 32.00 & 95 & 78 & 59 & 15.78 & 15 & 38 & - & 0.4 & - \\
\hline $15 \mathrm{R}-1,113-115$ & 32.14 & 82 & 75 & 92 & 17.00 & 12 & 60 & 56 & 0.7 & 0.6 \\
\hline $15 \mathrm{R}-1,133-134$ & 33.58 & 141 & 72 & 150 & 11.44 & 31 & - & - & - & - \\
\hline $15 \mathrm{R}-1,135-137$ & 33.72 & 172 & 74 & 141 & 15.40 & 28 & 92 & 92 & 0.5 & 0.7 \\
\hline $16 \mathrm{R}-1,40-48$ & 33.90 & 109 & 44 & 67 & 23.20 & 12 & - & - & - & - \\
\hline $16 \mathrm{R}-1,48-50$ & 34.02 & 111 & 47 & 57 & 15.52 & 18 & 37 & - & 0.3 & - \\
\hline $16 \mathrm{R}-1,88-90$ & 42.54 & 84 & 46 & 38 & 17.47 & 12 & 34 & - & 0.4 & - \\
\hline 18R-1, 22-24 & 39.40 & 88 & 44 & 80 & 17.57 & 13 & - & - & - & - \\
\hline $18 \mathrm{R}-1,28-30$ & 40.65 & 77 & 36 & 92 & 26.50 & 7 & 49 & 42 & 0.6 & 0.5 \\
\hline $18 \mathrm{R}-1,38-40$ & 42.24 & 74 & 48 & 39 & 18.70 & 10 & 24 & - & 0.3 & - \\
\hline $19 \mathrm{R}-1,13-15$ & 47.32 & 100 & 51 & 43 & 19.36 & 13 & 37 & - & 0.4 & - \\
\hline $19 \mathrm{R}-1,15-17$ & 47.80 & 75 & 46 & 78 & 20.70 & 9 & 50 & 35 & 0.7 & 0.4 \\
\hline
\end{tabular}

The most reasonable interpretation seems to be the recording of an excursion of the geomagnetic field. However much more information is necessary to confirm this suggestion.

The negative inclinations have been also observed by Johnson and Atwater (1977) in their FAMOUS collection using different orienting techniques. Two of the nine oriented samples (with respect to the vertical) gave negative inclinations (one of which with three cooling levels). However, Prévot et al. (1976) reported no negative inclination amongst their 18 oriented samples from FAMOUS area; the mean value of inclination corresponds well to that of the present geomagnetic field at the site. The criterion used by them was in most cases, the occurrence of frozen-in lava levels resulting in the formation of ledges assumed to be horizontal.

\section{ANHYSTERETIC REMANENT MAGNETIZATION (ARM)}

ARM is often used as an analogy to TRM and can give some information about magnetic grain structures within the samples. Generally, ARM is weaker than TRM (or NRM for submarine basalts). The ratio $\mathrm{J}_{\mathrm{a}} / \mathrm{J}_{\mathrm{n}}$ is usually found to be less than 1 (Levi and Merrill, 1976; Hamano et al., 1979). ARM has been obtained in direct field of $\mathrm{h}=0.4 \mathrm{Oe}$, by stepwise increase of alternating field $\mathrm{H}$. A line was then fitted to linear part of ARM vs. $1 / \mathrm{H}$ curve to obtain the saturation value of ARM by extrapolation. $\mathrm{J}_{\mathrm{a}} / \mathrm{J}_{\mathrm{n}}$ varies from 0.3 to 1.0 and is not significantly different for pillow or massive basalts. One source of uncertainty of $\mathrm{J}_{\mathrm{a}} / \mathrm{J}_{\mathrm{n}}$ is that we do not know exactly 
A
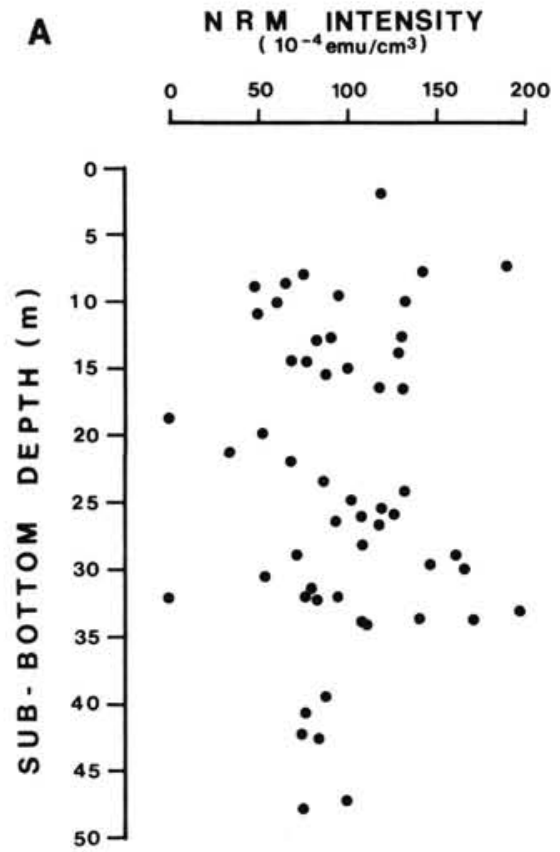

B

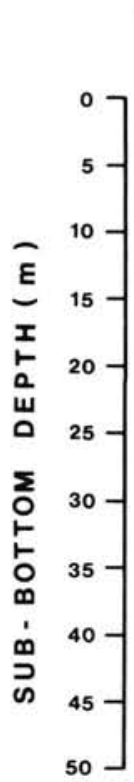

STABLE INCLINATIONS (Degrees)

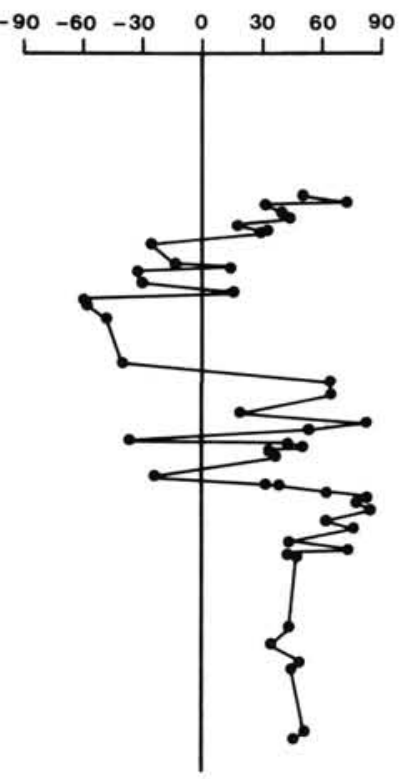

C $M_{(0 e)} D^{2}$

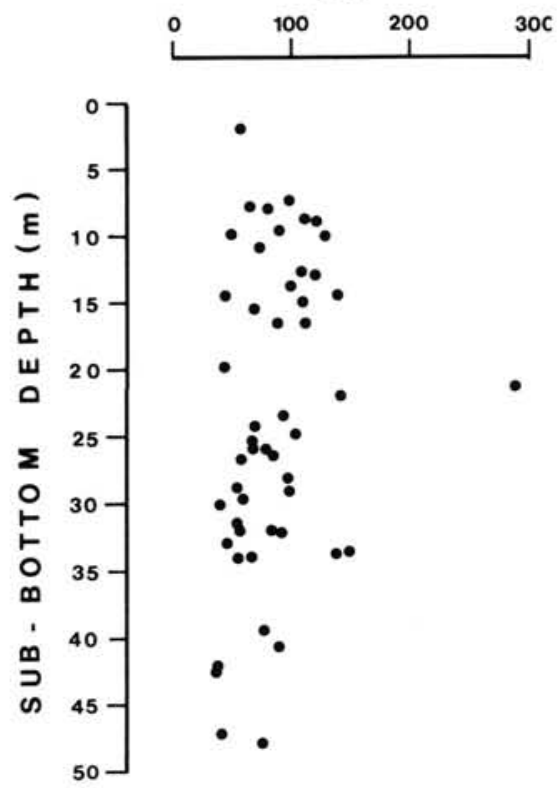

D
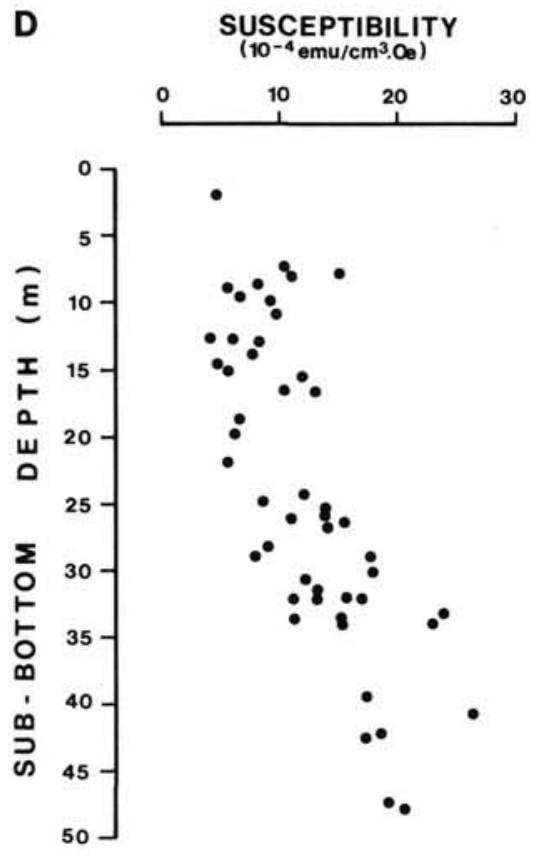

$\mathbf{E}$

Q RATIO
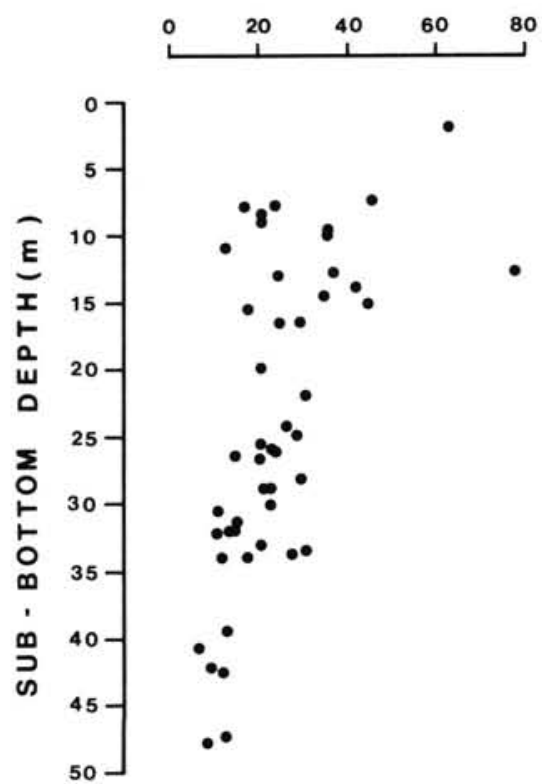

Figure 1. Variation with depth of A. NRM. B. Stable inclination of NRM. C. MDF. D. Magnetic susceptibility $\chi$. E. Koenigsberger ratio Q.

the inducing field of the NRM. $\mathrm{MDF}_{\mathrm{a}}$ (of the ARM) is also significantly less than $\mathrm{MDF}_{\mathrm{n}}$ (of the NRM), averaging for $\mathrm{MDF}_{\mathrm{a}} / \mathrm{MDF}_{\mathrm{n}}=0.7$. The same behavior is observed for Legs 82 and 83 basalts (Smith and Banerjee, 1985). In natural materials, where different magnetic grain sizes are usually present, $\mathrm{MDF}_{\mathrm{a}}$ reflects the portion of grains affected by the maximum of the alternating field and would be less than $\mathrm{MDF}_{n}$, since NRM concerns all grains including the grains having blocking/unblocking field larger than the applied AF field.

\section{COMPARISON WITH OTHER RECENT BASALTS FROM MID-OCEANIC RIDGES}

Magnetic parameters of pillow basalts from the FAMOUS zone, from CYAMEX-RISE, and from GEOMETEP on the East Pacific Ridge are presented in Table 3. Dredged basalts from these sites have ages between 0.02 and 0.1 m.y. and a low degree of alteration. Their magnetic parameters indicate the contribution of fine grained PSD to SD titanomagnetites (Smith, 1984; Prevot et al., 1981). Magnetic grain size of Hole 


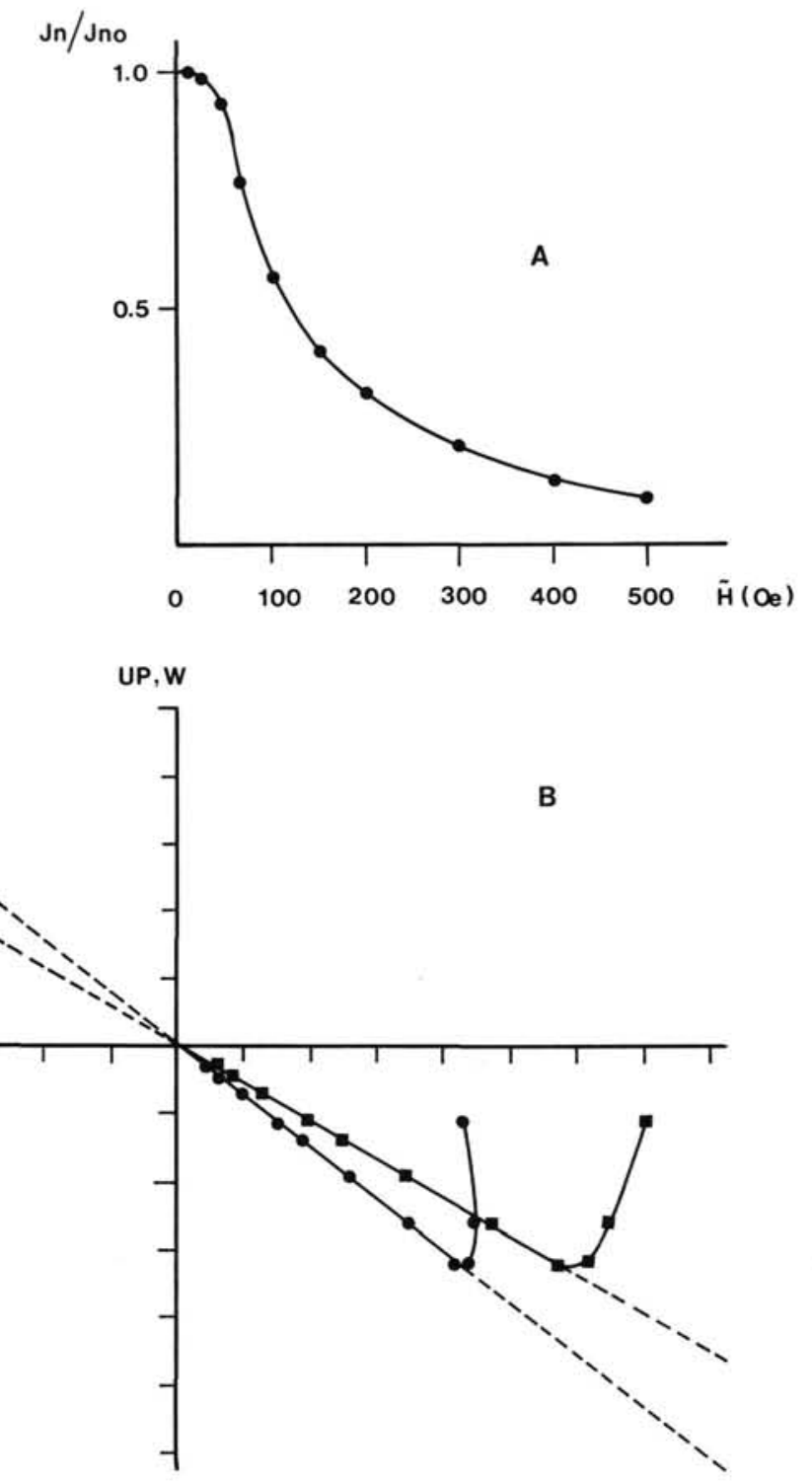

Figure 2. Sample $648 \mathrm{~B}-1 \mathrm{R}-2,124-126 \mathrm{~cm}$. A. Stepwise alternating field demagnetization of NRM. B. Zijderveld plot.

648B basalts seems to be much larger than that for FAMOUS or CYAMEX-GEOMETEP pillow basalts. This can be seen from the MDF or $\mathrm{H}_{\mathrm{c}}$ of different sites.

\section{SUMMARY AND CONCLUSION}

The most interesting paleomagnetic results of these "zero age" basalts are:

1. The negative inclination of NRM within approximately $10-20 \mathrm{~m}$ depth. If the hypothesis of collapse of a part of rocks or rotation of core pieces during drilling could be dismissed, then this zone must correspond to one of the recent Brunhes excursions (see, e.g., Verosub and Banerjee, 1977).

2. The NRM is a primary TRM with no secondary component, except a soft VRM. Very slight change with depth of the susceptibility, Q ratio, and MDF can be explained by an increase of magnetic grain sizes from pillow to massive basalts. The carriers of the magnetization of all samples seem to be titanomagnetite with PSD grains close to MD size, contrary to other recent mid-oceanic pillow basalts. This behavior may be due to the low degree of maghemitization which has not yet divided titanomagnetite grains to smaller sizes (Johnson and Hall, 1977; Petersen et al.,1979) or longer cooling time of these basalts compared to other dredged pillow basalts. The latter suggestion should be supported by petrological factors rather than magnetic parameters.

\section{REFERENCES}

Detrick, R. B, Honnorez, J., Bryan, W. B., Juteau, T., et al., 1988. Proc. ODP, Init. Repts., 106/109: College Station, TX (Ocean Drilling Program).

Hamano, Y., Nishitani, T., and Kono, M., 1979. Magnetic properties of basalts samples from Deep Sea Drilling Project Holes 417D and 418A. In Donnelly, T., Francheteau, J., Bryan, W., Robinson, P., Flower, M., and Salisbury, M., Init. Repts. DSDP, 51, 52, 53 (Pt. 2); Washington (U.S. Govt. Printing Office), 1391-1405.

Johnson, H. P., and Atwater, T., 1977. Magnetic study of basalts from the Mid-Atlantic Ridge, lat. $37^{\circ}$ N. Geol. Soc. America Bull., 88:637-647.

Johnson, H. P., and Hall, J. M., 1978. A detailed rock magnetic and opaque mineralogy study of the basalts from Nazca Plate. Geophys. J. R. Astron. Soc., 52:45-64.

Le Goff, M., 1985. Description d'un appareil à desaimanter par champs alternatifs; elimination de l'aimantation rémanente anhystérétique parasite. Can. J. Earth Sci., 22:1740-1747.

Levi, S., and Merrill, R., 1976. A comparison of ARM and TRM magnetite. Earth Planet. Sci. Lett., 32:171-184.

Petersen, N., Zisenach, P., and Bleil, U., 1979. Low temperature alteration of magnetic minerals in oceanic basalts. In Deep Drilling Results in Atlantic Ocean: Ocean Crust: Am. Geophys. Union, Maurice Ewing ser., 2:169-209.

Prévot, M., Lecaille, A., Francheteau, J. and Hekinian, R., 1976. Magnetic inclination of basaltic lavas from the Mid-Atlantic Ridge near $37^{\circ} \mathrm{N}$. Nature, 259:649-653.

Prévot, M., Lecaille, A., and Mankinen, E. A., 1981. Magnetic effects of maghemitization of oceanic crust. J. Geophys. Res., 86:40094020.

Smith, B., 1984. Propérités magnétiques de roches basaltiques provenant de la couche 2 de la croute océanique. Effet du degrée de cristallisation et de l'alteration basse température. [Ph.D. dissert.] Univ. Paris 6.

Smith, G. M., and Banerjee, S. K., 1985. Magnetic properties of basalts from Deep Sea Drilling Project Leg 83: The origin of remanence and its relation to tectonic and chemical evolution. In Anderson, R. N., Honnorez, J., Adamson, A. C., et al., Init. Repts. DSDP, 83: Washington (U.S. Govt. Printing Office), 37-357.

Verosub, K. L., and Banerjee, S. K., 1977. Geomagnetic Excursions and their paleomagnetic record. Rev. Geophys. Space Phys., $15: 145-155$.

Date of initial receipt: 7 April 1988

Date of acceptance: 19 December 1988

Ms 106/109B-157 
Table 2. TRM acquisition test for some samples having negative inclinations (see text).

\begin{tabular}{lrcccccccccc}
\hline \multicolumn{3}{c}{} & \multicolumn{3}{c}{$\begin{array}{c}\text { Heating } \\
\text { temperature }\end{array}$} & \begin{tabular}{c}
$\mathrm{h}$ \\
\multicolumn{1}{c}{ Samples }
\end{tabular} & $\mathrm{J}_{\mathrm{n}}$ & $\begin{array}{c}\left.{ }^{\circ} \mathrm{C}\right) \\
(\mathrm{Oe})\end{array}$ & $\mathrm{TRM}$ & $\begin{array}{c}\mathrm{MDF}_{\mathrm{t}} \\
(\mathrm{Oe})\end{array}$ & \multicolumn{3}{c}{$\%$} & $\mathrm{~J}_{\mathrm{s}}$ & $\mathrm{J}_{\mathrm{rs}}$ & $\mathrm{H}_{\mathrm{c}}$ & $\mathrm{H}_{\mathrm{cr}}$ \\
\hline $3 \mathrm{R}-1,29-31$ & 118 & 275 & 0.4 & 160 & 57 & +8 & +3 & -1 & -6 & -1.5 \\
$5 \mathrm{R}-1,4-6$ & 88 & 275 & 0.4 & 100 & - & +14 & - & - & - & - \\
$15 \mathrm{R}-1,58-60$ & 110 & 275 & 0.4 & 120 & - & +24 & - & - & - & - \\
\hline
\end{tabular}

Note: $\mathrm{J}_{\mathrm{n}}$ and TRM: intensity of NRM and TRM acquired in field $\mathrm{h}$, in $10^{-4} \mathrm{emu} / \mathrm{cm}^{3} ; \mathrm{J}_{\mathrm{s}}$ and $\mathrm{J}_{\mathrm{rs}}$ : induced and remanent saturation magnetizations. $\mathrm{H}_{\mathrm{c}}$ and $\mathrm{H}_{\mathrm{cr}}$ : coercive and remanent coercive forces.

Table 3. Comparison between some magnetic properties from Hole $648 \mathrm{~B}$ and some other recent mid-oceanic pillow basalts.

\begin{tabular}{llllllll}
\hline \multicolumn{1}{c}{ Site } & \multicolumn{1}{c}{$\mathrm{J}_{\mathrm{n}}$} & \multicolumn{1}{c}{$\chi$} & $\mathrm{Q}$ & $\mathrm{MDF}_{\mathrm{n}}$ & $\mathrm{J}_{\mathrm{rs}} / \mathrm{J}_{\mathrm{s}}$ & $\mathrm{H}_{\mathrm{cr}} / \mathrm{H}_{\mathrm{c}}$ & References \\
\hline FAMOUS & 144 & 3 & 151 & 359 & 0.49 & 1.43 & Prévot et al. (1981) \\
& $(103)$ & $(103)$ & $(103)$ & $(53)$ & $(53)$ & $(53)$ & \\
CYAMEX- & 82 & 3 & 183 & 481 & 0.52 & 1.34 & Smith (1984) \\
GEOMETEP & $(55)$ & $(55)$ & $(55)$ & $(62)$ & $(14)$ & $(14)$ & \\
648B & 104 & 13 & 25 & 88 & 0.24 & 1.7 & This work \\
& $(53)$ & $(50)$ & $(48)$ & $(52)$ & $(15)$ & $(15)$ & \\
\hline
\end{tabular}

Note: same definitions as Table 2; value in parentheses is number of studied samples. 